Uniwersytet w Białymstoku

Wydział Filologiczny

Instytut Filologii Wschodniosłowiańskiej

tel.: +48 857457499

e-mail: anna.rygorowicz-kuzma@uwb.edu.pl

ORCID ID: https://orcid.org/0000-0002-5100-6045

\title{
Rutenizmy w staropolskiej terminologii religijnej (na przykładzie Stownika staropolskiej terminologii chrześcijańskiej Marii Karpluk)
}

Słowa kluczowe: rutenizmy, terminologia religijna, język staropolski, prawosławie

Terminologia religijna $\mathrm{w}$ języku polskim to zagadnienie badawcze ciekawe zarówno w perspektywie współczesnej, jak i historycznej. Językoznawcy doszli do pewnego konsensusu, uznając, że najstarsza polska leksyka religijna w dużej mierze została zapożyczona z języka czeskiego, skąd na ziemie polskie trafiło chrześcijaństwo ${ }^{1}$. Nie jest to jednak jedyna droga przenikania tego słownictwa do języka polskiego ${ }^{2}$. Niniejszy artykuł jest próbą prezentacji leksyki religijnej o możliwym pochodzeniu wschodniosłowiańskim.

Przedstawiony poniżej materiał leksykalny dotyczy najstarszego okresu w historii rozwoju języka polskiego, trwającego od zaczątków jego doby piśmiennej tzn. od ok. połowy XII wieku do przełomowych dziesięcioleci XV i XVI w. ${ }^{3}$ Rutenizmy są tu rozumiane jako zapożyczenia z języków wschodniosłowiańskich, ruskich, obejmujące zarówno staroukrainizmy,

\footnotetext{
1 Zob. np.: Klich 1927, s. 147; Brückner 1957, s. 236; Klemensiewicz 1985, s. 29; Karpluk 1999; Bednarczuk 2017 i in. Por. też np. Matla 2012.

2 Mowa tu np. o bezpośrednim wpływie niemieckim (zob. np. Czarnecki 1999) czy staro-cerkiewno-słowiańskim (zob. Siatkowski 1982; zob. też m.in.: Lanckorońska 1961, Kmietowicz 1994, Żerelik 1999, Mironowicz 2006, s. 26-46 i in.)

3 Zob. np. Klemensiewicz 1985, I, 31.
} 
jak też pożyczki staroruskie czy starobiałoruskie. Bazę źródłową stanowi Stownik staropolskiej terminologii chrześcijańskiej autorstwa Marii Karpluk (dalej SKarp.), praca niezwykle ważna i jak do tej pory jedyna, poza niedokończoną monografiac Polska terminologia chrześcijańska Edwarda Klicha [Klich 1927], poświęcona najstarszemu słownictwu religijnemu w języ$\mathrm{ku}$ polskim w stopniu tak obszernym ${ }^{4}$. Analiza wyekscerpowanych z tego źródła jednostek leksykalnych przeprowadzona jest z wykorzystaniem metody strukturalno-semantycznej oraz metody pola semantycznego.

Chrześcijaństwo dotarło na ziemie polskie jeszcze przed oficjalną datą chrztu Polski, to jest przed rokiem 966. Według Zenona Klemensiewicza: „Wpływy chrześcijańskie oddziaływały już na dłuższy czas przedtem, w ciągu wieku X, a może i u schyłku IX, na Śląsk i ziemię Wiślan, kiedy te obszary należały do państwa Mojmirowiców morawskich (...), a po jego zaś katastrofie dostały się pod zwierzchnictwo czeskie" [Klemensiewicz 1985, t. I, 28]. Chrystianizacja ziem czeskich odbywała się pod wpływem dwóch głównych misji: salzburskiej i cyrylo-metodejskiej, stykały się więc w niej zarówno wpływy łacińsko-niemieckie, jak i grecko-cerkiewnosłowiańskie. Misja salzburska rozprzestrzeniała się wśród Słowian zachodnich już od VIII w., a na początku IX w. dotarła na Morawy ${ }^{5}$. Jej językiem liturgicznym była łacina, misyjnym zaś - staro-wysoko-niemiecki ${ }^{6}$. Wschodni wymiar chrześcijaństwa czeskiego związany był z działalnością na tych terenach Cyryla i Metodego, braci uznanych za świętych, zwanych też apostołami Słowian? Misjonarze przybyli do państwa wielkomorawskiego w 863 roku na zaproszenie księcia Rościsława, który chciał schrystianizować swoje ziemie w obrządku i języku dla ludności zrozumiałym ${ }^{8}$. Pamiętać należy, że był to jeszcze okres jedności chrześcijaństwa, rozłam na Kościół katolicki i prawosławny dokonał się formalnie w roku 1054. Pomimo początkowego sukcesu misji cyrylo-metodejskiej, jej losy na ziemiach czeskich okazały się bardzo zmienne. Wpływy liturgii słowiańskiej zauważalne tam były do XII wieku ${ }^{9}$ W wiekach kolejnych nastąpiła dominacja wpływów niemieckich i łacińskich.

4 W słowniku zarejestrowane są 2592 hasła, opisane i opracowane w sposób bardzo rzetelny i szczegółowy. Autorka nie tylko objaśnia znaczenia i ilustruje obecność leksyki religijnej w najstarszych zabytkach piśmienniczych, ale też stara się ukazać możliwe drogi wejścia poszczególnych leksemów do staropolskiej terminologii chrześcijańskiej. Zob. SKarp., s. X-XIX.

5 Zob. np. Moszyński 2006, s. 87-88.

6 Zob. np. Moszyński 1999, s. 7.

7 Zob. np. Moszyński 2006, s. 106

8 Szerzej na ten temat zob. np. Moszyński 2006, s. 106-112.

9 Zob. np. Moszyński 2006, s. 68. 
W najstarszej, sięgającej jeszcze okresu przedpiśmiennego, leksyce polskiej dotyczącej chrześcijaństwa trudno jest raczej mówić o zapożyczeniach typowo ruskich. Jak już wspomniano, leksyka ta to przede wszystkim bohemizmy. Co prawda, wyróżnimy tu dość liczebną grupę leksemów obecnych w języku staro-cerkiewno-słowiańskim, które są podstawą religijnej terminologii wschodniochrześcijańskiej, ale trafiały one wówczas na ziemie polskie raczej bez pośrednictwa ruskiego, najczęściej poprzez pośrednictwo czeskie, por. np. apostoł, bezwinny, błogosławienie. W niektórych przypadkach mogły być to jednak zapożyczenia bezpośrednie.

Badając najstarsze słownictwo religijne dotyczące cerkiewizmów Janusz Siatkowski wyróżnia trzy podstawowe grupy: wyrazy rodzime, słowiańskie, które nabrały znaczenia religijnego jeszcze przed okresem cyrylo-metodejskim (np. terminy bóg, duch, grzech, kazanie), wyrazy zapożyczone w okresie przedcyrylo-metodejskim (np. z łaciny bałkańskiej ołtarz, poganin, pop) oraz cerkiewizmy powstałe w okresie działalności Cyryla i Metodego (np. błogostawić, bogurodzica, kwietna niedziela, uczennik, wszechmogacy) [Siatkowski 1982]. W tej ostatniej grupie większość stanowią kalki z języka greckiego (ale też łaciny), choć są i twory rodzime. Część z nich do terminologii polskiej trafiła poprzez pośrednictwo czeskie (np. błogostawić, rozgrzeszyć, licemiernik), część jednak, jak sugeruje Siatkowski, mogła pojawić się w języku polskim bezpośrednio, w okresie oddziaływania na południu ziem polskich liturgii słowiańskiej. Taką proweniencję mogły mieć wyrazy miłosierdy, zbawić, Zbawiciel, samnienie/sumienie [Siatkowski 1982, 98]. Jeszcze inną prawdopodobną drogą jest przenikanie podobnych leksemów z terenów Rusi Kijowskiej ${ }^{10}$. Do takiego pochodzenia części terminów chrześcijańskich naukowcy odnoszą się raczej sceptycznie. Wydaje się jednak, iż Ruś, jako centrum chrześcijaństwa wschodniego poprzez bliskie sąsiedztwo z państwem polskim, ciągłe stosunki polityczne i handlowe oraz liczne związki małżeńskie pierwszych Piastów z księżniczkami ruskimi mogła jednak w pewnym stopniu wpływać na oblicze chrześcijaństwa polskiego.

O wyraźnych wpływach ruskich na słownictwo chrześcijańskie w języku polskim możemy na pewno mówić od wieku XIV, kiedy to królowie polscy rozpoczęli ekspansję na wschód i południowy wschód. Za panowania Kazimierza Wielkiego do Polski przyłączona została ziemia sanocka i przemyska (1344 r.), Ruś Halicka, Lwów, Chełm, Bełz, Brześć i Włodzimierz Wołyński (1349 r.) [Mironowicz 2006, 115-118]. Po zawarciu unii krewskiej z Litwą

10 Zob. na ten temat m.in.: Rospond 1966, s. 31; Łużny 1993, s. 266; Białokozowicz 2006, s. $26 \mathrm{i}$ in. 
w roku 1385 kultura ruska przenikała na ziemie polskie również z terytorium Wielkiego Księstwa Litewskiego ${ }^{11}$. Część ludności tych terenów wyznawała prawosławie, do języka polskiego wchodziło więc słownictwo religijne dotyczacce Cerkwi jako instytucji i wyznania.

Stanisław Urbańczyk, redaktor naczelny Stownika staropolskiego, wyekscerpował z pierwszych opublikowanych tomów i indeksu do tego dzieła około 150 wyrazów, które uznał za zapożyczenia z języka ukraińskiego [Urbańczyk 1963]. Wśród tej leksyki Maria Karpluk wyróżniła kilkanaście leksemów należących do leksyki religijnej, dotyczących Kościoła wschodniego. Są to: bat'ko (w zapisie bajtko), czerniec, diaczek, diak, humion, kryłos, maślnica, metropolit, monastyr, popadia, popowic, popowski, popowy, prazniczne, prażnik, proskura, wieńczanie, władyka [Karpluk 2010, 228]. Wiesław Witkowski, pisząc o zapożyczeniach wschodniosłowiańskich wynotowanych ze Stownika staropolskiego, grupę leksemów o tematyce religijnej stawia na drugim - co do znaczenia - miejscu ${ }^{12}$. Włącza on do niej następujące rutenizmy: bajtko (być może), bies, czerniec//czyrniec, epifania, harchimandryta, humen//humion, kryłos, maślnica, mitropolit, monaster//monastyr, popadyja//popadynia, popowic, popowski, prażniczny, prażnik, proskura, proskurnica, soroczyny, Spas, spasienie, wieńczanie, władyka, wtadystwo [Witkowski 2013, 162-163].

Wschodniosłowianizmy wyekscerpowane ze Stownika staropolskiej terminologii chrześcijańskiej [SKarp.] stanowią większą liczebnie grupę niż te, wymieniane przez Stanisława Urbańczyka czy Wiesława Witkowskiego. Sa to: harchimendryta, batwan, batwański, bat'ko, bajtko, batko, bies, błogostawiać, bogobojny, Bogorodzica, bogostawić, bogostawienie, czerniec, czyr(z)niec, dyjak, homion, humien, humion, jenorodny, kryłos, kum, maślnica, metropolit, mitropolit, modlitwnik, monaster, manaster, manastyr, manastyrz, monasterz, monastyr, monastyrz, naśladownik, paschowy, pokajać sie, pomiłować, popadyja, popowic, poragać, poraganie, prawdziwy, prażniczny, prażik, proskura, praskura, proskurnica, praskurnica, proskornica, przeczysta, przepowiednica, przepowiednik, rozpiać, Spas, spasienie, uciesznik, wieńczanie, władystwo, władyka, włodyka, wplecenie, wwiedienie, wypiewać, wyszny, wyszni, wzbłogosławić, zapust, zapusty, zaszczyciciel, zaszczyciel, zaszczyćciel, zaszczytciel, Złotousty, żela. Należy jednak zaznaczyć, że leksemy te w wielu przypadkach są rutenizmami prawdopodobnymi, ale nie pewnymi. Włączona jest do nich np. forma bies, która znajduje poświadcze-

11 Zob. np. Walczak 2018, s. 278-280.

12 Najbardziej liczną grupą słownictwa proweniencji ruskiej w SStp są według Wiesława Witkowskiego leksemy z dziedziny administracji, ekonomii i prawa. 
nie zarówno w źródłach staroczeskich, cerkiewnosłowiańskich, jak i staroruskich. Prawdopodobnie jednak weszła ona do polszczyzny z Rusi, gdyż, być może ze względów tabuistycznych, była rzadko spotykana w tekstach staropolskich ${ }^{13}$. Leksem epifania wymieniony przez Wiesława Witkowskiego jako zapożyczenie wschodniosłowiańskie nie znalazł się w powyższej grupie. Co prawda nie jest on poświadczony w czeszczyźnie, ale jest najprawdopodobniej bezpośrednią pożyczką z łaciny kościelnej (a tam z greki, por.

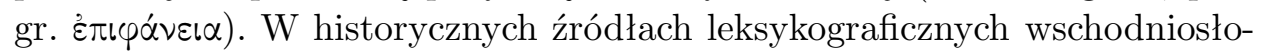
wiańskich leksem ten występuje rzadko, zob. епифание [Srez. I, 830], brak wyrazu w SRJ XI-XVII oraz słownikach języka starobiałoruskiego i staroukraińskiego. Synonimiczna nazwa wskazująca na święto Objawienia Pańskiego, która była aktywna w językach ruskich to богоявление, strukturalno-semantyczna kalka greckiego $\vartheta \varepsilon o \varphi \alpha ́ v \varepsilon ı$.

Biorąc pod uwagę stronę znaczeniową wyekscerpowanych z SKarp. leksemów, można wśród nich wydzielić:

- nazwy i atrybuty Boga, Matki Bożej i świętych: Bogarodzica, Bogorodzica - 'Matka Boska' [SKarp., 8], jenorodny - 'o Jezusie: syn jedyny, pierworodny' [SKarp., 50], prawdziwy - 'atrybut Boga: dotrzymujący obietnic' [SKarp., 172], Spas - 'o Chrystusie: Zbawiciel' [SKarp., 211], Złotousty 'św. Jan Chryzostom' [SKarp., 344], uciesznik - 'o Bogu': a. 'o Bogu Stwórcy i Chrystusie: ten, który sprawia pocieszenie' b. 'o Duchu Świętym: Pocieszyciel' [SKarp., 248], zaszczyciciel, zaszczyciel, zaszczyćciel, zaszczytciel 'o Bogu: obrońca' [SKarp., 328-329];

- nazwy osób związanych z życiem Cerkwi, duchowieństwa i laikatu: harchimendryta - 'przełożony większej liczby klasztorów w Cerkwi prawosławnej' [SKarp., 30], bat'ko, bajtko, batko - 'o księdzu prawosławnym: ojciec (duchowny)' [SKarp., 4], czerniec, czyr(z)niec - 'mnich Cerkwi prawosławnej; archimandrita' [SKarp., 23], dyjak - 'śpiewak cerkiewny, pomocnik księdza' [SKarp, 28], homion, humien, humion - 'w Cerkwi prawosławnej przełożony monasteru' [SKarp., 47], kryłos - 'kler, duchowni posługujący w cerkwi' [SKarp., 67], kum - 'ojciec chrzestny w stosunku do matki chrzestnej i do rodziców dziecka, a także ojciec dziecka w stosunku do jego rodziców chrzestnych' [SKarp., 71], metropolit, mitropolit - 'metropolita (w Cerkwi wschodniej)' [SKarp., 87], modlitwnik - 'czciciel, wyznawca' [SKarp., 97], naśladownik - 1. 'wzorujący się (na Chrystusie)' 2. 'czciciel (bożków)' 3. 'postępujący według czegoś, zwolennik' [SKarp., 1030], ormiańczyk, ormieńczyk - 'człowiek pochodzenia lub (i) wyznania ormiańskiego'

13 Zob. SKarp., s. 6. Por. też np. SEBru., s. 26; SEBor., t. I, s. 28; SESław., t. I, s. 33; w SG leksem nie został poświadczony. 
[SKarp., 137], popadyja, popadynia, popodia, popodyja, popodyni, popodynia - 'żona prawosławnego kapłana' [SKarp., 163], popowic, popowicz - 'syn prawosławnego kapłana' [SKarp., 163], proskurnica, praskurnica, proskorni$c a-1$. 'piekarnia, w której wypieka się proskury' 2. 'kobieta wypiekająca proskury' [SKarp., 176], władyka, włodyka - 'tytuł biskupa i metropolity w Cerkwi prawosławnej' [SKarp., 287], władystwo - 'biskupstwo w Cerkwi prawosławnej' [SKarp., 287];

- nazwy budynków i pomieszczeń kościelnych oraz ich części: bożnica - 'świątynia' a. 'w Starym Testamencie: synagoga' b. 'świątynia pogańska' c. 'cerkiew prawosławna, też przy prawosławnym monasterze' [SKarp., 12], monaster, manaster, manastyr, manastyrz, monasterz, monastyr, monastyrz - 1. 'monaster, klasztor w Cerkwi Wschodniej' 2. 'klasztor w Kościele ormiańskim' [SKarp., 97];

- nazwy religijnych okresów, świąt i zwyczajów (i ich derywaty) oraz nazwy nabożeństw i związanych z nimi utensyliów: maślnica - 'ostatnia niedziela przed Wielkim Postem' [SKarp., 85], paschowy - 'wielkanocny' [SKarp., 144], prażniczny - 'związany z uroczystością cerkiewną zwaną prażnikiem' [SKarp., 173], prażnik - 'uroczystość cerkiewna związana z określonym świętem' [SKarp., 173], proskura, praskura - 'chleb liturgiczny używany w Cerkwi prawosławnej' [SKarp., 176], soroczyny - '40-dniowy okres po śmierci, poświęcony pamięci zmarłego' [SKarp., 211], wieńczanie - 'cerkiewny obrzęd sakramentu małżeństwa (z nakładaniem wieńców tj. koron, na głowy młodych)' [SKarp., 282];

- nazwy określające relacje człowiek - Bóg: błogosławiać - 'w relacji człowieka do Boga: wielbić' [SKarp. 7-8], bogobojny - 'w relacji człowieka do Boga: pobożny' [SKarp., 8], bogosławić - 1. 'w relacji człowieka do Boga: wielbić' 2. 'w relacji Boga do człowieka: poświęcać, nadawać moc zbawienną' [SKarp. 9], bogosławienie - 'w relacji człowieka do NMP: wielbienie' [SKarp., 9], pokaźn - 'nakaz (boży)' [SKarp.,156], pomiłować - 'w relacji Boga do ziemi i ludzi: ulitować się, użalić się' [SKarp., 160], poragać - 'w relacji człowieka do Boga: bluźnić, znieważać' [SKarp., 163], poraganie - 'w relacji człowieka do Boga: bluźnienie, znieważanie' [SKarp., 163], wypiewać - 'czcić śpiewem, opiewać (NMP)' [SKarp., 303], żela - 'w relacji człowieka do Boga: żal (za grzechy)' [SKarp., 358];

- pojęcia teologiczne: ameń - 'uroczyste zapewnienie: tak jest, niech tak się stanie, wypowiadane na końcu modlitwy' [SKarp., 1], potop - 'zesłany przez Boga powodziowy kataklizm jako kara za grzechy' [SKarp., 168], spasienie - 'w tłumaczeniu łac. hebraizmu „hosanna", modlitewnego okrzyku ST: zbawienie; hosanna' [SKarp., 211], wpłecenie - 'o Synu Bożym: przyjęcie ciała ludzkiego' [SKarp., 290]; 
- określenia idoli i duchów upadłych: bałwan - 'bożek' [SKarp., 4], bies - 'diabel' [SKarp., 5-6].

Przytoczony powyżej materiał leksykalny w większości charakteryzuje duchowość i kulturę religijną Cerkwi prawosławnej, choć część terminów to też pojęcia ogólnochrześcijańskie (np. jenorodny, kum, modlitwnik, pomiłować i in.). Najbardziej reprezentatywną grupę stanowią tu nazwy dotyczacce osób (duchownych i świeckich) oraz określenia ich relacji z Bogiem. Mniej licznie poświadczone są terminy związane z obrzędowością prawosławną, parę leksemów dotyczy pojęć teologicznych.

Od strony etymologicznej badane rutenizmy można podzielić na:

- zapożyczenia greckie, które zostały przejęte przez języki ruskie naj-

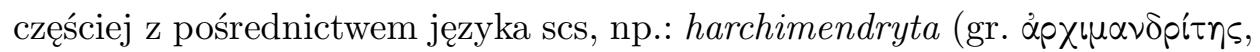
scs. -, strus. архимандрить, архимандрита) ${ }^{14}$, homion, humien, humion

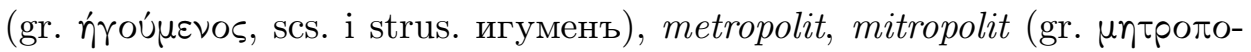

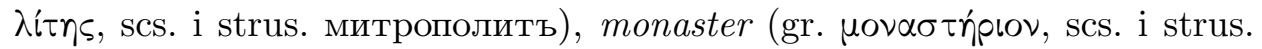
манастырь, монастырь) i in.

- kalki strukturalno-semantyczne $\mathrm{z}$ greki, obecne również $\mathrm{w}$ języku

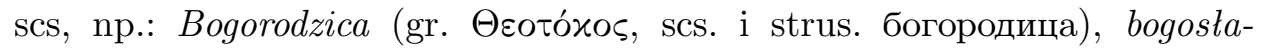

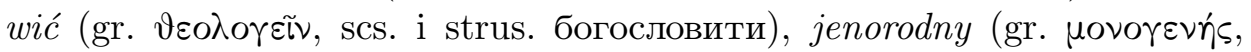

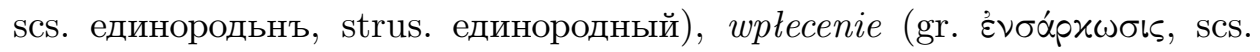
въплъщение, strus. въплъщение) i in.

- wyrazy pochodzenia staro-cerkiewno-słowiańskiego, przejęte przez języki ruskie, np.: czerniec, czyr(z)niec (scs. чрьньць, чръньць, strus. чьрньць, чрьньць, чернець), pokaźń (scs. i strus. показнь), przeczysta (scs.

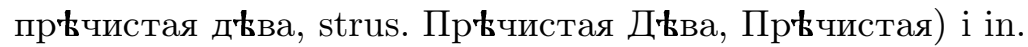

- wyrazy pochodzenia ruskiego, np.: bat'ko (scs. -, strus. батько), proskurnica (scs. -, strus. проскурьница) i in.

- wyrazy ogólnosłowiańskie „zapożyczone” ze słownictwa przedchrześcijańskiego, np. bies (stczes. běs, scs. i strus. бłcъ).

- wyrazy o innej etymologii, np. batwan ${ }^{15}$ (scs. -, strus. бълъванъ, болванъ, балъванъ) i in.

Wnikając do języka polskiego rutenizmy ulegały polonizacji bądź zachowywały cechy ruskie. Przykładem adaptacji do polskiego systemu fonetycznego są m.in. wyrazy bogosławić (wtórne -sław-), harchimendryta (spółgło-

14 Formy greckie, cerkiewnosłowiańskie, staroruskie, staroczeskie i inne przytaczane w niniejszej pracy pochodzą z następujących źródeł leksykograficznych: Fas, LLP, Srez., SRJ XI-XVII, SSUM. Niektóre z form źródłowych przytaczane są za SKarp.

15 Pożyczka ruska z języków orientalnych. Zob. SKarp., s. 4. Por. też SEBor., s. 21; SESław., t. I, s. 26; SG, s. 5. 
ska protetyczna $h$ - w nagłosie, -men-), jenorodny (uproszczenie grupy - $d n$ $\mathrm{w}-n$-), przepowiednik (przejście prefiksu pro- w prze-), Złotousty (złoto-) i in. $\mathrm{W}$ formach bat'ko, batko, wwiedienie, monastyr, manastyr i in. zachowane są cechy wschodniosłowiańskie. Ciekawymi przykładami krzyżowania się obu obszarów językowych są leksemy ameń, ekswładyka (łac. eks-i scs. władyka), manastyrz, monastyrz (scs. monastyr i pol. -rz), ormiańczyk, ormieńczyk (ruskie orm-, rodzime -czyk), popowic (spolszczenie odojcowskiego -icz na -ic), prażnik (uproszczenie grupy spółgłoskowej -zdn-) i in.

Ruskie pochodzenie analizowanych tu leksemów religijnych, co zostało już wcześniej zasygnalizowane, nie jest pewne, ale możliwe. Znaczne prawdopodobieństwo wschodniosłowiańskiego (bądź cerkiewnosłowiańskiego) pośrednictwa zauważamy w przypadku terminów, które nie znajdują fiksacji w słownikach staroczeskich, a nie są też bezpośrednim pożyczkami łacińskimi. Odnotowane są za to w słownikach języka staro-cerkiewno-słowiańskiego i języków ruskich. Do takich zaliczymy formy błogosławiać (stczes. -, scs. i strus. благословляти), bogostawić (stczes. -, scs. i strus. богословити), bogostawienie (stczes. -, scs. i strus. богословление), czerniec $^{16}$, czyr(z)niec (stczes. črnec - tylko w nazwach własnych, scs. чрьньць, чрьньць, strus. чьрньць, чрьньць, чернець, черенец), dyjak (stczes. -, scs. дияк, strus. диякъ, диакъ, дьякъ, дьакъ), homion, humien, humion (stczes. -, scs. i strus. игуменъ), rryłos $^{17}$ (stczes. -, scs. клиросъ, strus. i stukr. крылосъ), kum ${ }^{18}$ (stczes. -, scs. кумъ, strus. i stukr. кумъ), maślnica (stczes. -, scs. маслинница, масльница 'drzewo oliwne', strus. масльная недњля), mitropolit, metropolit (stczes. -, scs. i strus. митрополить), monaster, manaster, manastyr, manastyrz, monasterz, monastyr, monastyrz (stczes. manstyř, tylko w znaczeniu 'klasztor w Sazawie', scs. i strus. манастыръ, монастыръ), pokaźn (stczes. -, scs. i strus. показнь), potop (stczes. -, jest potopa (fem.), scs. i strus. потоп), praskura, proskura (stczes. -, jest praskora, scs. проскура, просфора, strus. проскура, проскора, просфора i in.), praw-

16 W SStp. termin czerniec nie występuje w znaczeniu 'mnich', poświadczona jest tylko nazwa botaniczna.

17 W Stowniku staropolskim wyraz kryłos odnotowany jest w niespotykanym znaczeniu 'świątynia, cerkiew prawosławna' [SStp. III, t. 6, 411]. Maria Karpluk podaje zaś znaczenie: 'kler, duchowni posługujący w cerkwi' [SKarp., 67]. Por. też SRJ XI-XVII w.: krylos - 1. 'собир. клир, священнослужители, весь церковный притч' 2. 'собир. младшие члены церковного притча' 3. 'место для певчих в церкви по правую и левую сторону от амвона; клирос' [VIII, 94]. Wyjściowa forma tego terminu to kliros (z jezzyka greckiego), która w językach wschodniosłowiańskich w wyniku przestawki l-r (być może pod wpływem wyrazu крыллo) uzyskała też formę kryłos, zob. np. ESUM III, s. 92.

18 Por. też np. SEBor., SESław. 
dziwy (stczes. -, scs. правьдивъ, strus. правьдивыи), prażnik (stczes. ${ }^{-19}$, scs. i strus. праздьникъ), przepowiednik (stczes. -, scs. i strus. проповедьникъ), przepowiednica ${ }^{20}$ (stczes. -, scs. проповедьница, strus. проповедница), władyka $a^{21}$ (stczes. ${ }^{22}$, scs. i strus. владыка), wpłecenie (stczes. -, scs. въплъщение, strus. въплъщение), wwiedienie (stczes. -, scs. i strus. въведение), zaszczyciciel, zaszczyciel, zaszczyćciel, zaszczytciel (stczes. -, scs. защитель, strus. защититель). Dość pewne pośrednictwo ruskie mają też następujące wyrazy, niepoświadczone nie tylko w języku staroczeskim, ale też staro-cerkiewno-słowiańskim: harchimendryta (stczes. -, scs. -, strus. архимандритъ, архимандрита), batwan (stczes. ${ }^{-23}$, scs. - , strus. бъльванъ, болванъ, блъванъ, балъванъ), batwański (stczes. -, scs. -, strus. болванский), bat'ko, bajtko, batko (stczes. -24, scs. -, strus. батько), ormiańczyk, ormieńczyk (stczes. -, scs. -, strus. - stukr. орменьскии, орменскы), popadyja, popadynia, popodia, popodyja, popodyni, popodynia (stczes. -, scs. -, strus. попадья), ророwic, ророwicz (stczes. ${ }^{-25}$, scs. -, strus. поповичь), prażniczny (stczes. -, scs. -, strus. праздьничьныи), proskurnica, praskurnica, proskornica (stczes. -, scs. -, strus. проскуръница), исіеsznik (stczes. -, scs. -, jest утешитель, strus. утешьникъ), soroczyny (stczes. -, scs. -, strus. сорочины), wieńczanie (stczes. -, scs. -, jest веньчати, strus. веньчание), wypiewać (stczes. -, scs. -, strus. выпевати), zapust, zapusty (stczes. -, scs. -, strus. запустъ, запускъ, stukr. запусты).

Niepewne, choć możliwe pośrednictwo ruskie występuje dla wyrazów poświadczonych w języku staroczeskim, ale wykazujących tė̇ pewne cechy (fonetyczne, morfologiczne, strukturalne) wschodniosłowiańskie, bądź wskazujących na duchowość i organizację Kościoła wschodniego. Do takich leksemów możemy zaliczyć na przykład terminy pomiłować czy władystwo. Pierwszy z nich, czasownik pomiłować poświadczony jest w języku staroczeskim (stczes. pomilovati), ale forma miłować z prefiksem po- nie jest zbyt typowa dla języka polskiego (por. formy stpol. zmiłować (się), smiłować (się), smiłowanie, smiłowny), występuje za to aktywnie w językach ruskich,

\footnotetext{
19 W języku staroczeskim tylko w znaczeniu 'próżniak'. Za: SKarp., s. 173.

20 Wpływ ruski bądź derywat od przepowiednik.

21 Por. też. SEBru, s. 40.

22 W języku staroczeskim leksem vladyka poświadczony jest w innych znaczeniach.

23 Stczes. balvan tylko w znaczeniu 'miara soli'. Za: SKarp., s. 4.

$24 \mathrm{~W}$ języku staroczeskim występuje tylko forma bat'a i zdrobnienie bat'ek w znaczeniu 'brat, krewny, przyjaciel' [za: SKarp., 4-5].

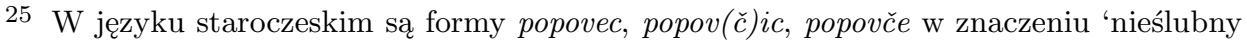
syn księdza katolickiego' [za: SKarp., 162].
} 
por. помилование, помиловати [Srez. II, 1158], помилование, помиловати, помиловатися [SRJ XI-XVII, z. 17, 19-20]. Drugi z kolei przykład władystwo (stczes. vladyčstvie, vladyčstvo, scs. i strus. владычьство) obecny zarówno w języku staroczeskim, jak i staro-cerkiewno-słowiańskim oraz ruskim odnosi się do nomenklatury Kościoła wschodniego, prawdopodobnym jest więc jego przenikanie z ziem wschodnich. Inne wyrazy włączone do tej grupy to: bogobojny (stczes. bohobojny, scs. -, strus. богобойный), Bogorodzica (stczes. bohorodice ${ }^{26}$, scs. i strus. богородица), bożnica (stczes. božnice, scs. -, strus. божьница), jenorodny (w stczes. jest forma: jednorodily; w scs. единородьнъ, w strus. единородный), modlitwnik (stczes. modlitevnik, scs. i strus. молитвьникъ), poragać (stczes. poruhati, scs. поржгати, strus. поругати), poraganie (stczes. poruhanie, scs. поржгание, strus. поругание, поруганье), Przeczysta (stczes. přěcista, scs. пречистая дева, strus. Пречистая, Пречистая Дева, Пречистая Мати), rozpiać, rozpięty (stczes. rozpaty, scs. распьти, strus. распяти, распятъ), Spas (stczes. Spas, scs. Съпасъ, strus. Спасъ), Wyszny, Wyszni (stczes. Vyšni, Vyšny, scs. i strus. Вышьнии).

Podsumowując powyższe rozważania, z dużą dozą prawdopodobieństwa można stwierdzić, że część staropolskiej leksyki religijnej miała wschodniosłowiańskie pochodzenie. Dotyczy to zwłaszcza leksyki wskazującej na duchowość Kościoła prawosławnego, przenikającej z terenów, na których prawosławie było wyznaniem dominującym. Niektóre z tych nazw, np. przeczysta (por. Przeczysta Panna), kum, zapusty przetrwały i są obecne we współczesnym języku polskim, część terminów, np. Bogorodzica, kryłos, monaster, Spas, władyka, wwiedienie używana jest do dziś w mowie i piśmie społeczności prawosławnej w Polsce, inne z kolei jak poraganie, pomiłowaćp ${ }^{27}$, soroczyny, pokaźn z czasem wyszły z użycia.

\section{Wykaz skrótów}

ESUM - Etimologıčnij slovnik ukraïns'koï movi, t. 1-6, red. O.S. Mel'ničuk, Kï̄ 1982-2012. [Етимологичний словник украӥнської мови, т. 1-6, ред. О.С. Мельничук, Київ 1982-2012.]

Fas. $\quad$ - Fasmer M., Ètimologičeskij slovar' russkogo âzyka, t. 1-4, Moskva 1986- 1987. [М. Фасмер, Этимологический словарь русского языка, т. 1-4, Москва 1986-1987.]

$26 \mathrm{~W}$ języku staroczeskim jest to forma rzadka i nie ma wariantów [SKarp., 8].

27 Wyraz ten, również w znaczeniu 'zmiłować się', jest jeszcze obecny w SJPD. 
LLP - Slovnik jazyka staroslověnského. Lexicon linguae paleoslovenicae, sv. I- IV, Praha 1966-1997.

SEBor. - Boryś W., Stownik etymologiczny języka polskiego, Kraków 2005.

SEBru. - Brückner A., Stownik etymologiczny jezzyka polskiego, Warszawa 1989.

SESław. - Sławski F., Stownik etymologiczny języka polskiego, t. 1-5, Kraków 1952-1982.

SG - Glosariusz staropolski. Dydaktyczny stownik etymologiczny, red. W. Decyk-Zięba, S. Dubisz, Warszawa 2008.

SJPD - Stownik języka polskiego, red. W. Doroszewski, t. I-XI, Warszawa 1958-1969.

SKarp. - Stownik staropolskiej terminologii chrześcijańskiej, Kraków 2001.

Srez. - Sreznevskij I. I., Materialy dlâ Slovarâ drevnerusskogo âzyka, t. 1-3, Moskva 1958. [И. И. Срезневский, Материальь для Словаря древнерусского языка, т. 1-3, Москва 1958.]

SRJ XI-XVII- Slovar' russkogo âzyka XI-XVII vv., Moskva 1975-. [Cловарь pycского языка XI-XVII вв., Москва 1975-.]

SSUM - Slovnik staroukraïns'koï movi XIV-XV st., red. L. L. Gumec'ka, t. 1-2, Kï̈v 1977-1978. [Словник староукраїнської мови XIVXV cm., ред. Л. Л. Гумецька, т. 1-2, Київ 1977-1978.]

SStp. $\quad-$ Stownik staropolski, red. S. Urbańczyk, t. I-XI, Kraków 1953-2002.

\section{Literatura}

Bednarczuk L., 2017, Językowe drogi chrystianizacji Polski, „Poznańskie Spotkania Językoznawcze", t. 34 (2017), Poznań, s. 7-34.

Białokozowicz B., 2006, U źródet cyrylickiego piśmiennictwa południowostowiańskiego oraz jego percepcji na gruncie wschodniostowiańskim i polskim, „Acta Polono-Ruthenica, t. XI, Olsztyn, s. 7-28.

Brückner A., 1957, Dzieje kultury polskiej, t. I, Od czasów przedhistorycznych do r. 1506, Warszawa.

Czarnecki T., 1999, Najstarsze polskie słownictwo religijne o rodowodzie niemieckim, [w:] Tysiac lat polskiego stownictwa religijnego, red. B. Kreja, Gdańsk, s. $13-28$.

Karpluk M., 1999, O staropolskiej terminologii chrześcijańskiej (inspiracje czeskie), [w:] Tysiac lat polskiego stownictwa religijnego, red. B. Kreja, Gdańsk 1999, s. $29-33$.

Karpluk M., 2010, Z prawostawnego stownictwa ruskiego w polszczyźnie XVI wieku, [w:] Staropolskie studia językoznawcze, Kraków, s. 227-233.

Klemensiewicz Z., 1985, Historia języka polskiego, cz. 1-3, Warszawa.

Klich E., 1927, Polska terminologia chrześcijańska, Poznań. 
Kmietowicz F., 1994, Kiedy Kraków byt „Trzecim Rzymem”, Białystok.

Lanckorońska K., 1961, Studies on the Roman-Slavonic Rite in Poland, Rome.

Łużny R., 1993, Kultura chrześcijańska Dawnej Rusi w optyce polskiej - wczoraj $i$ dziś, [w:] Teologia i kultura duchowa Starej Rusi, red. W. Hryniewicz, J.S. Gajek, Lublin, s. 265-286.

Matla M., 2012, Czeskie wpływy kulturowe w jezyku i piśmiennictwie państwa piastowskiego (od X do XIV wieku) w świetle historiografii polskiej, „Historia Slavorum Occidentis" t. 2(3), 210-232.

Mironowicz A., 2006, Kościól prawosławny w Polsce, Białystok.

Rospond S., 1966, Chrystianizacja Polski a badania jezykoznawcze, „Nasza przeszłość", t. XXV, s. 7-32.

Moszyński L., 1999, Poczatti słowiańskiego słownictwa religijnego, [w:] Tysiac lat polskiego słownictwa religijnego, red. B. Kreja, Gdańsk, s. 7-12.

Moszyński L., 2006, Wstęp do filologii słowiańskiej, Warszawa.

Siatkowski J., 1982, O cerkiewizmach w najstarszej polskiej terminologii chrześcijańskiej, [w:] Zeszyty Naukowe Wydziału Humanistycznego, Slawistyka 3, Polskie kontakty z piśmiennictwem cerkiewnosłowiańskim do końca wieku XV, Gdańsk, s. 97-105.

Urbańczyk S., 1963, Charakterystyka staropolskich zapożyczeń wyrazowych z języka ukraińskiego, [w:] Studia linguistica in honorem Thaddaei Lehr-Spławiński, red. T. Milewski, J. Safarewicz, F. Sławski, Warszawa, s. 437-444.

Walczak B., 2018, Ruszczyzna - drugi język Rzeczypospolitej, [w:] Języki ruskie $w$ rozwoju historycznym i kontaktach z polszczyzna, red. L. Citko, Białystok, s. $277-287$.

Witkowski W., 2013, Jeszcze raz o najdawniejszych zapożyczeniach ruskich (wschodniosłowiańskich) w języku polskim, „Rocznik Slawistyczny”, t. LXII, Kraków, s. 159-167.

Żerelik R., 1999, Obrzadek słowiański w południowej Polsce, [w:] Prawosławie. Światło wiary $i$ zdrój doświadczenia, red. K. Leśniewski, J. Leśniewska, Lublin, s. 439-447.

\section{LOAN WORDS FROM THE RUTHENIAN LANGUAGE IN OLD POLISH RELIGIOUS TERMINOLOGY (ON THE EXAMPLE OF SEOWNIK STAROPOLSKIEJ TERMINOLOGII CHRZEŚCIJAŃSKIEJ BY MARIA KARPLUK)}

\section{S U M M A R Y}

Key words: loan words from the Ruthenian language, religious terminology, Old Polish language, Orthodoxy

Religious terminology in the Polish language is an interesting topic and constantly requires academic research. Linguists have reached a certain consensus that 
the oldest Polish Christian lexicon to a large extent was borrowed from the Czech language along with the spread of Christianity from that area. This article addresses the issue of Polish religious terminology that could have Eastern Slavic origins. They were taken from Maria Karpluk's graphic lexicon entitled A Dictionary of Old Polish Christian Terminology (Stownik staropolskiej terminologii chrześcijańskiej) and were analyzed in terms of semantics and etymology.

The analysed lexicon particularly relates to the spirituality of the Orthodox Church that originates from areas where Orthodoxy was the dominant religion. Some of the words, e.g. przeczysta (compare Przeczysta Panna), kum, zapusty have survived and are present in contemporary Polish, while others such as poraganie, pomiłować, soroczyny, pokaźn gradually disappeared. Some Old Polish religious terms of Eastern Slavic origin such as Bogorodzica, kryłos, monaster, Spas, władyka, wwiedienie are used today in both in oral and written forms in the Orthodox community in Poland. 